\title{
A new and efficient procedure for the synthesis of hexahydropyrimidine-fused 1,4-naphthoquinones
}

\author{
Marcelo Isidoro P. Reis ${ }^{1}$, Vinícius R. Campos ${ }^{1}$, Jackson A. L. C. Resende ${ }^{2}$, \\ Fernando C. Silva ${ }^{1}$ and Vitor F. Ferreira*1
}

\section{Full Research Paper}

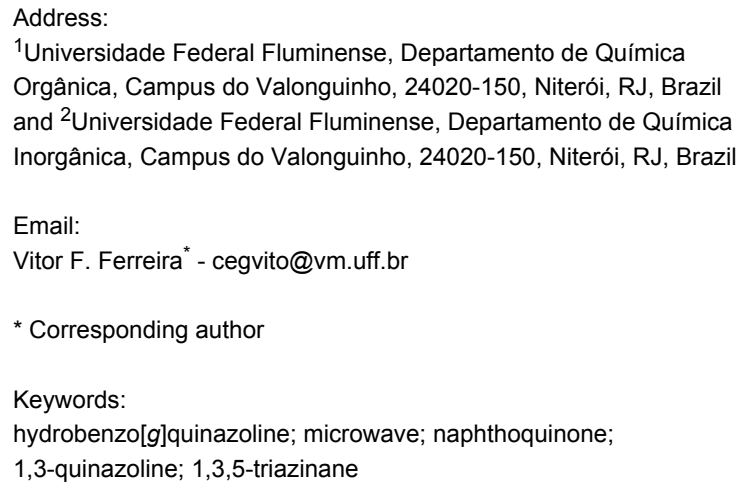

${ }^{1}$ Universidade Federal Fluminense, Departamento de Química Orgânica, Campus do Valonguinho, 24020-150, Niterói, RJ, Brazil and 2 Universidade Federal Fluminense, Departamento de Química Inorgânica, Campus do Valonguinho, 24020-150, Niterói, RJ, Brazil

Beilstein J. Org. Chem. 2015, 11, 1235-1240. doi:10.3762/bjoc.11.137

Received: 31 May 2015

Accepted: 03 July 2015

Published: 22 July 2015

Associate Editor: T. J. J. Müller

(c) 2015 Reis et al; licensee Beilstein-Institut. License and terms: see end of document.

\section{Abstract}

A new and efficient method for the synthesis of hexahydropyrimidine-fused 1,4-naphthoquinones in one step with high yields from the reaction of lawsone with 1,3,5-triazinanes was developed.

\section{Introduction}

Quinones represent a diverse family of naturally occurring secondary metabolites [1-3]. Interest in these substances has intensified in recent years due to their pharmacological importance [4]. Heterocycle-fused naphthoquinones (Figure 1) such as naphtho[2,3-b]furan [5-14], naphtho-pyran [15-18], benzo[f]indole [19-24], benzo[g]quinolone [25], benzo[b]carbazole [26], naphtho[2,3-b]thiophene [27-33] and naphtho[2,3-b]] oxazole [34] have been demonstrated to display various biological activities. There are several specific and general methods reported in the literature that describe the preparation and biological activity of heterocycle-fused naphthoquinone compounds [35]. Recently, Iida et al. described a general method for the construction of pyrrole-, furan- and thiophene-fused naphthoquinones [36].

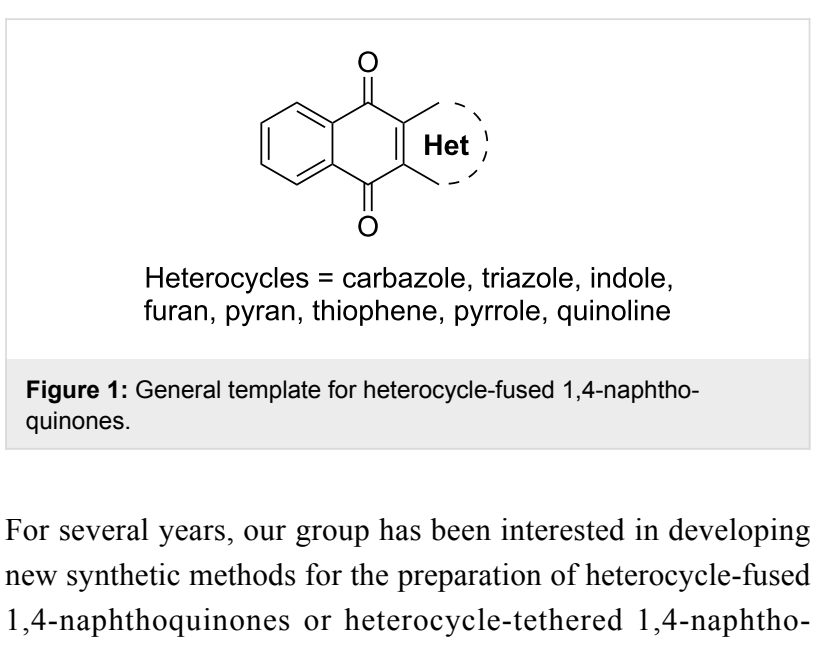


quinones. 1,3-Quinazolines are nitrogenated heterocycles that are present in several products. However, there are only three procedures for the preparation of hexahydropyrimidine-fused 1,4-naphthoquinones available. Some of them are restrictive, troublesome and produce the hexahydropyrimidine-1,4-naphthoquinones in low yields. Möhrle and Herbruggen synthesized unsymmetrical hexahydropyrimidine-fused 1,2- and 1,4-naphthoquinones by the reaction of 4-amino-1,2-naphthoquinone and 2-amino-1,4-naphthoquinone with amines and formaldehyde in moderate yields [37]. Ohta et al. studied the nucleophilic addition reaction of methylamine to 2-bromo-3-hydroxymethyl-1,4naphthoquinone (1) and obtained hexahydropyrimidine-fused 1,4-naphthoquinone (5) as side product (Scheme 1) [38,39] This reaction was non-selective and formed a mixture of four products (2-5) that are derived from the addition of methylamine to both of the electrophilic sites of the starting material $\mathbf{1 .}$ In the same publication, the authors reported another method that was more selective, which involved the addition of two equivalents of a monoalkyl amine $\left(\mathrm{R}-\mathrm{NH}_{2}\right)$ to menadione $(6)$ to give hexahydropyrimidine-fused 1,4-naphthoquinones 5, 11-13 in low yields.

\section{Results and Discussion}

Herein we describe a new method for the synthesis of hexahydropyrimidine-fused 1,4-naphthoquinones (13 and 21-25) in high yields, from the sequential reaction of readily available 1,3,5-triazinanes 14-19 with 2-hydroxy-1,4-naphthoquinone (20, or lawsone) under microwave irradiation (Scheme 2).<smiles>O=C1C(Br)=C(CO)C(=O)c2ccccc21</smiles>

1<smiles>CC1=CC(=O)c2ccccc2C1=O</smiles><smiles></smiles>

2, $40 \%$<smiles>CNCC1=C(Br)C(=O)c2cc[cH+]ccc2C1=O</smiles>

$3,13 \%$<smiles></smiles>

4, $17 \%$<smiles></smiles>

5, $8 \%$

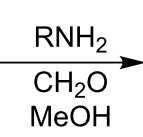

$\mathrm{MeOH}$<smiles>[R]NC1=C(C)C(=O)c2ccccc2C1=O</smiles>

7. $\mathrm{R}=\mathrm{Me}, 40 \%$

8, $R=\operatorname{Pr}, 39 \%$

9, $\mathrm{R}=\mathrm{iPr}, 34 \%$

$10, \mathrm{R}=\mathrm{Bu}, 28 \%$<smiles>[R]N1CC2=C(C(=O)c3ccccc3C2=O)N([R])C1</smiles>

5. $\mathrm{R}=\mathrm{Me}, 35 \%$

11, $R=\operatorname{Pr}, 23 \%$

12, $R=i \operatorname{Pr}, 23 \%$

$13, R=B u, 21 \%$

Scheme 1: Methods for the preparation of hexahydropyrimidine-fused 1,4-naphthoquinones

$$
\begin{aligned}
& \mathrm{R}-\mathrm{NH}_{2}+\mathrm{CH}_{2} \mathrm{O}_{(\mathrm{aq})} \frac{\text { toluene, reflux }}{30 \mathrm{~min}} \\
& \text { 14, } R=\text { butyl, } 75 \% \\
& \text { 15, } \mathrm{R}=\text { pentyl, } 89 \% \\
& \text { 16, } \mathrm{R}=\text { decyl, } 70 \% \\
& \text { 17, R= benzyl, } 90 \% \\
& \text { 18, } R=4 \text {-chlorobenzyl, } 85 \% \\
& \underbrace{O H}_{20} \underset{150^{\circ} \mathrm{C}, 15 \mathrm{~min}}{\mathrm{CHCl}_{3}, \mathrm{MW}}
\end{aligned}
$$


The 1,3,5-triazinanes have several synthetic and biological applications [40]. These substances are easily prepared from commercially available amines and formaldehyde in toluene in yields ranging from $75-90 \%$. Barluenga and coworkers [41] have previously shown that 1,3,5-triazinanes undergo fragmentation at elevated temperatures to form 3 equivalents of alkyl- or aryl-formimines in situ. The latter compounds may serve as electrophilic agents for aminoalkylation reactions. Our research group also investigated the aminoalkylation of 2-amino-1,4naphthoquinone with formaldehyde under microwave irradiation to produce two series of $N, O$-acetals and $N, S$-acetals. These compounds were obtained in good yields, and several of them showed promising antibacterial activity [42].

The structures of the synthesized 1,3,5-triazinanes were confirmed by spectroscopic techniques such as NMR, ${ }^{1} \mathrm{H}$ and ${ }^{13} \mathrm{C}-\mathrm{APT}$, infrared spectroscopy (FTIR) and high resolution mass spectrometry. The synthesis of compounds 14 [43] and 17 [44] has been previously reported in the literature. The structure of compound $\mathbf{1 8}$ was confirmed by X-ray diffraction analysis and Figure 2 shows the ORTEP diagram of this compound. The details of the crystal data and refinements are collected in Supporting Information File 1, Table S1.

The crystal structure of compound $\mathbf{1 8}$ contains two molecules per asymmetric unit. Two factors explain the differences between molecules A and B (Figure 2): (1) different intermolecular interactions and (2) small differences in the torsion angles of the $p$-substituted benzyl groups. The 1,3,5-triazinane rings of 18 (molecules A and B) adopt a chair conformation, with Cremer-Pople puckering parameters $q_{2}$ and $\Phi_{2}$ of 0.023(9) $\AA$ and $323.0(20)^{\circ}$, respectively, for molecule $\mathrm{A}$, and $q_{2}$ and $\Phi_{2}$ of $0.016(3) \AA$ and $2.0(25)^{\circ}$, respectively, for molecule B.

Next the reaction between 1,3,5-triazinanes 14-19 and 2-hydroxy-1,4-naphthoquinone (20) was developed to prepare fused hexahydropyrimidine-1,4-naphthoquinones 13 and 21-25 using in situ generated alkyl formimines. Performing the reaction without heating proceeds very slow and after 24 hours extensive degradation products were observed. By elevating the temperature and or changing the solvent some product is formed but the yields were very low. On the other hand, when the reactions were conducted in an equimolar ratio under microwave irradiation (300 Monowave model brand Aanton Paar) in chloroform for 15 minutes at a temperature of $150{ }^{\circ} \mathrm{C}$, the desired products were obtained in good yields $(75-80 \%$, Scheme 2). All structures of the benzo-fused tetrahydroquinazolines were characterized by ${ }^{1} \mathrm{H}$ NMR and ${ }^{13} \mathrm{C}$-APT, infrared spectroscopy (FTIR) and high resolution mass spectrometry. Using compound $\mathbf{2 3}$ as an example, it can be observed that its ${ }^{1} \mathrm{H}$ NMR spectrum contains a doublet of doublets $(J=0.98$ and $7.8 \mathrm{~Hz}$ ) at $7.98 \mathrm{ppm}$ attributed to the hydrogen H-5 of the naphthoquinone moiety, a multiplet at 7.16-7.25 ppm related to the aromatic protons on the phenyl ring (H-3"'-H, 7"'), and four singulets corresponding to the $\mathrm{H} 1$ ' $\left(\mathrm{C}-\mathrm{CH}_{2}-\mathrm{N}\right), \mathrm{H} 1$ " $\left(\mathrm{N}-\mathrm{CH}_{2}-\mathrm{N}\right), \mathrm{H}-1$ "' $\left(\mathrm{N}-\mathrm{CH}_{2}-\mathrm{Ph}\right)$ and $\mathrm{H}-1$ '"' $\left(\mathrm{N}-\mathrm{CH}_{2}-\mathrm{Ph}\right)$ methylene protons at $3.60 \mathrm{ppm}, 3.77 \mathrm{ppm}, 3.84 \mathrm{ppm}$ and $4.75 \mathrm{ppm}$, respectively. The high resolution mass spectrum of compound 23 showed a molecular ion $[\mathrm{M}+\mathrm{H}]^{+}$at $m / z$ 395.2062, which corresponds with the calculated mass for $\mathrm{C}_{26} \mathrm{H}_{22} \mathrm{~N}_{2} \mathrm{O}_{2} \mathrm{H}$ $[\mathrm{M}+\mathrm{H}]^{+}$of 395.1715. The structure of compound $\mathbf{2 3}$ was further elucidated by X-ray diffraction analysis (Figure 3). It

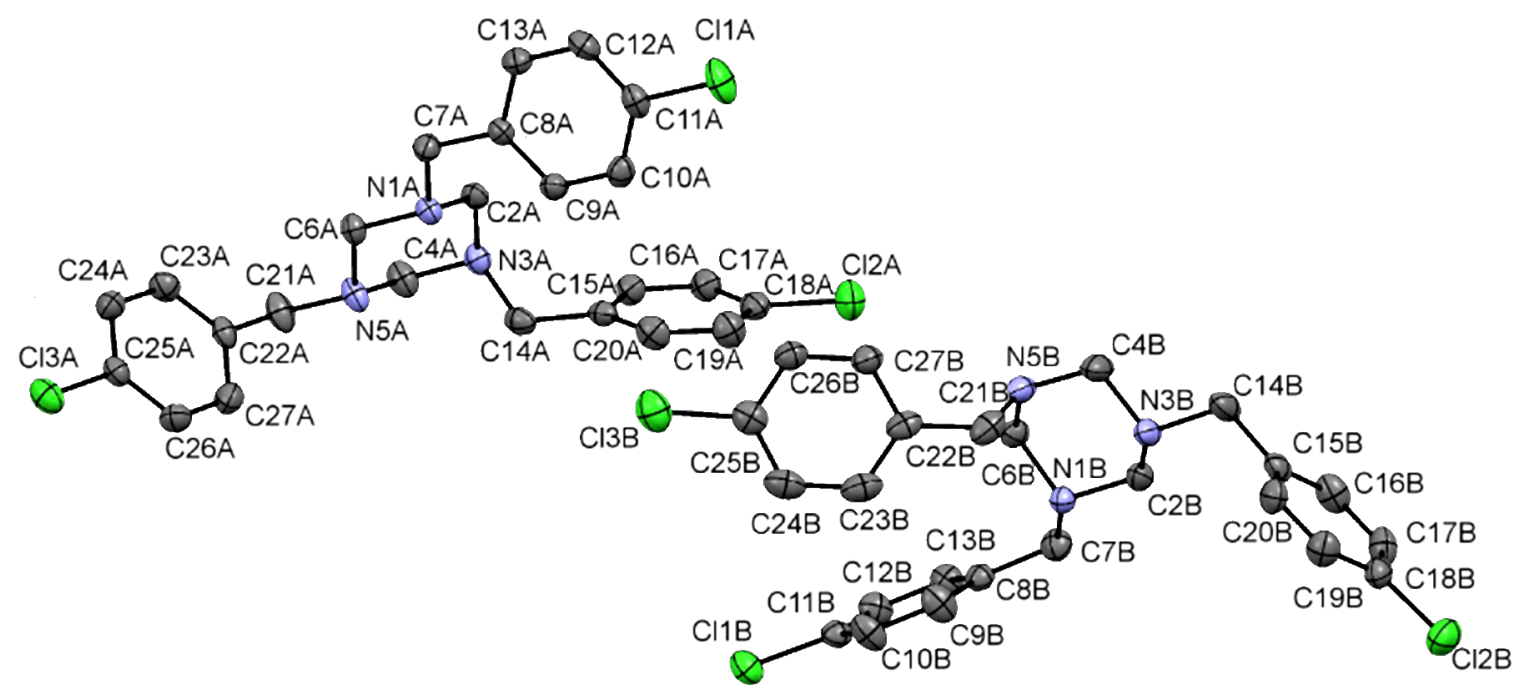

Figure 2: ORTEP diagram of compound 18 depicted with ellipsoids drawn at the $50 \%$ probability level and the atom-numbering scheme. 
confirmed the insertion of two imines to form a hexahydropyrimidine ring which is coupled to a 1,4-naphthoquinone moiety. Figure 3 shows the ORTEP diagram of compound $\mathbf{2 3}$ and the details of the crystal data and refinements are given in Supporting Information File 1, Table S2.

In the crystal structure, the six-membered nitrogen-containing ring of $\mathbf{2 3}$ adopts a half boat conformation (Cremer-Pople puckering parameters [45] $q_{2}$ and $\Phi_{2}$ of $0.374(9) \AA$ and $119.0(1))$ in which the $\mathrm{N}(3)$ atom is located at 0.641(2) $\AA$ out of the plane of the other five atoms $\mathrm{C}(2), \mathrm{N}(1), \mathrm{C}(4 \mathrm{a}), \mathrm{C}(10)$ and C(4).

A possible mechanism that could explain the formation of the tetrahydrobenzo[g]quinazolines $\mathbf{1 3}$ and $\mathbf{2 1 - 2 5}$ is shown in Scheme 3. It initially involves the in situ formation of three thermally generated iminium ions or the equivalent methylformimines from the corresponding triazinane which then react with lawsone (20) at its two nucleophilic sites, thus forming products (Scheme 3 ).

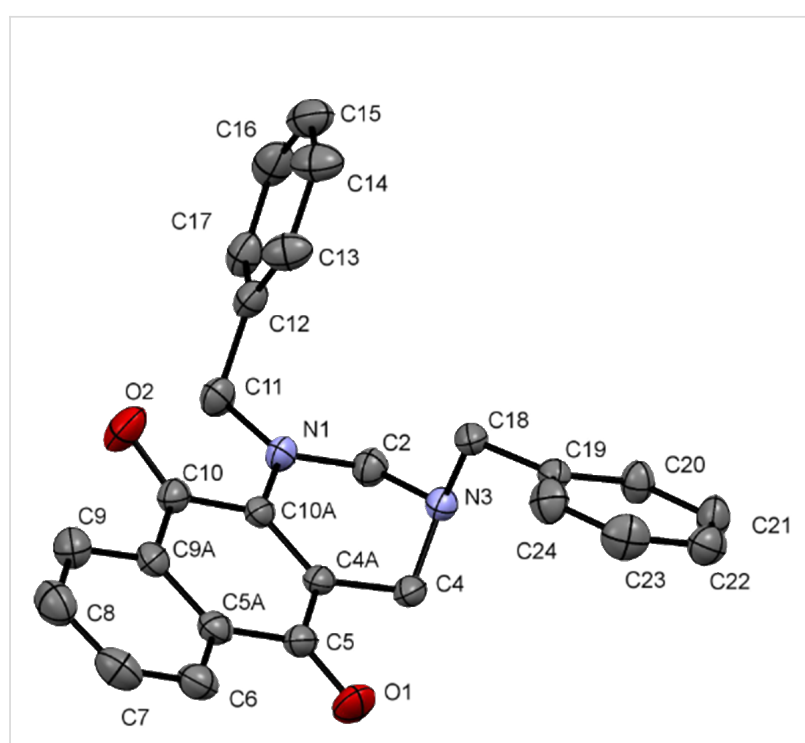

Figure 3: ORTEP diagram of compound 23 depicted with ellipsoids drawn at the $50 \%$ probability level and the atom-numbering scheme.<smiles>[R]N=C[CH+][C@H]1CC(=O)c2ccccc2C1=O</smiles><smiles>[R]N=CC1C(=O)C(=O)c2ccccc2C1=O</smiles>

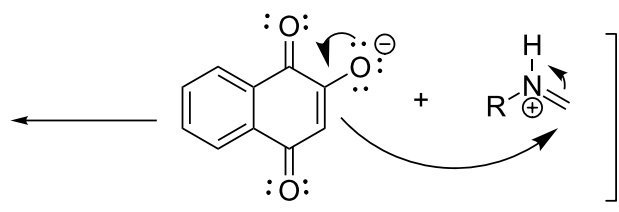

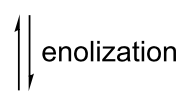

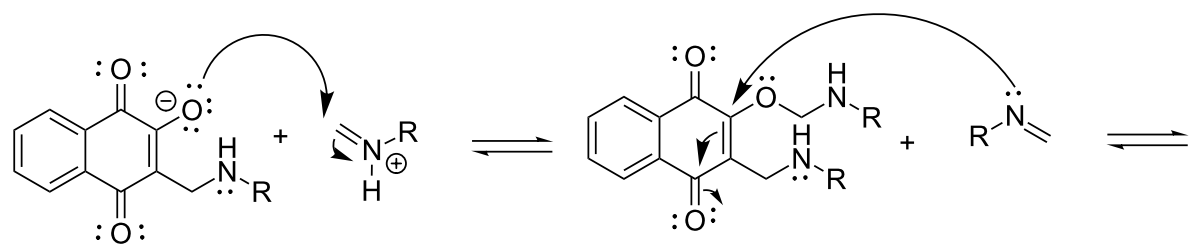

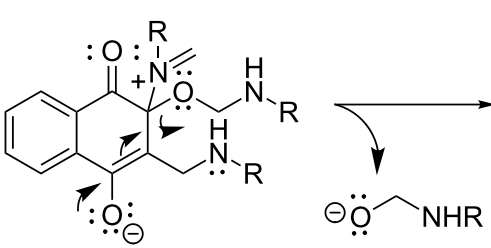

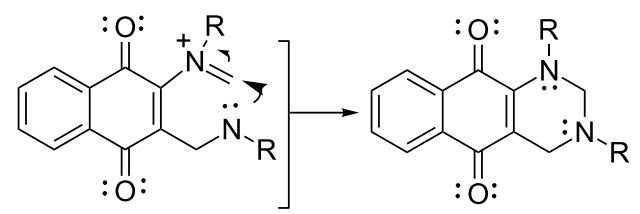

13 and $21-25$ 


\section{Conclusion}

A new method for the synthesis of new heterocyclic hexahydropyrimidines fused to a 1,4-naphthoquinone system (13 and 21-25) was developed. The products were obtained in one step, under microwave irradiation and with excellent yields. This method is a more efficient alternative for the preparation of benzo-fused tetrahydroquinazolindiones than the method described in the literature. The structures of all starting 1,3,5triazinanes and products were confirmed by spectroscopical methods and X-ray diffraction analysis.

\section{Supporting Information}

\section{Supporting Information File 1}

Experimental procedures and spectral data.

[http://www.beilstein-journals.org/bjoc/content/

supplementary/1860-5397-11-137-S1.pdf]

\section{Acknowledgements}

The authors thank the CAPES, CNPq and FAPERJ for funding this research project. The authors also thank LaReMN/UFF and LARE-DRX/UFF (FAPERJ) for the NMR and X-ray data.

\section{References}

1. Patai, S. The chemistry of the quinoid compounds; John Wiley \& Sons: London, England, 1974.

2. Patai, S.; Rappoport, Z. The Chemistry of the Functional Groups. The Chemistry of the Quinonoid Compounds; John Wiley \& Sons: New York, USA, 1988.

3. Thomson, R. H. Naturally Occurring Quinones IV; Blackie Academic \& Professional: London, England, 1997.

4. Ferreira, V. F.; da Rocha, D. R.; da Silva, F. C.; Ferreira, P. G.; Boechat, N. A.; Magalhães, J. L. Expert Opin. Ther. Pat. 2013, 23, 319-331. doi:10.1517/13543776.2013.749862

5. Rao, M. M.; Kingston, D. G. I. J. Nat. Prod. 1982, 45, 600-604. doi:10.1021/np50023a014

6. Cardoso, M. F. C.; Rodrigues, P. C.; Oliveira, M. E. I. M.; Gama, I. L.; da Silva, I. M. C. B.; Santos, I. O.; Rocha, D. R.; Pinho, R. T.;

Ferreira, V. F.; de Souza, M. C. B. V.; da Silva, F. d. C.; Silva, F. P., Jr. Eur. J. Med. Chem. 2014, 84, 708-717. doi:10.1016/j.ejmech.2014.07.079

7. Eyong, K. O.; Kumar, P. S.; Kuete, V.; Folefoc, G. N.; Nkengfack, E. A.; Baskaran, S. Bioorg. Med. Chem. Lett. 2008, 18, 5387-5390. doi:10.1016/j.bmcl.2008.09.053

8. Ferreira, M. d. P. S. B. C.; Cardoso, M. F. d. C.; da Silva, F. d. C.; Ferreira, V. F.; Lima, E. S.; Souza, J. V. B. Ann. Clin. Microbiol. Antimicrob. 2014, 13, No. 26. doi:10.1186/1476-0711-13-26

9. Teimouri, M. B.; Khavasi, H. R. Tetrahedron 2007, 63, 10269-10275. doi:10.1016/j.tet.2007.07.082

10. da Silva, A. J. M.; Netto, C. D.; Pacienza-Lima, W.; Torres-Santos, E. C.; Rossi-Bergmann, B.; Maurel, S.; Valentin, A.; Costa, P. R. R. J. Braz. Chem. Soc. 2009, 20, 176-182. doi:10.1590/S0103-50532009000100026
11. Ueda, S.; Umemura, T.; Dohguchi, K.; Matsuzaki, T.; Tokuda, H.; Nishino, H.; Iwashima, A. Phytochemistry 1994, 36, 323-325. doi:10.1016/S0031-9422(00)97069-9

12. Wu, C.; Johnson, R. K.; Mattern, M. R.; Wong, J. C.; Kingston, D. G. I. J. Nat. Prod. 1999, 62, 963-968. doi:10.1021/np9900019

13. Jiménez-Alonso, S.; Guasch, J.; Estévez-Braun, A.; Ratera, I.; Veciana, J.; Ravelo, A. G. J. Org. Chem. 2011, 76, 1634-1643. doi:10.1021/jo102233j

14. Reichstein, A.; Vortherms, S.; Bannwitz, S.; Tentrop, J.; Prinz, H.; Müller, K. J. Med. Chem. 2012, 55, 7273-7284. doi:10.1021/jm3009597

15. Ferreira, S. B.; da Silva, F. d. C.; Pinto, A. C.; Gonzaga, D. T. G.; Ferreira, V. F. J. Heterocycl. Chem. 2009, 46, 1080-1097. doi:10.1002/jhet.232

16. da Costa, E. C. B.; Amorim, R.; da Silva, F. C.; Rocha, D. R.; Papa, M. P.; de Arruda, L. B.; Mohana-Borges, R.; Ferreira, V. F.; Tanuri, A.; da Costa, L. J.; Ferreira, S. B. PLoS One 2013, 8, e82504. doi:10.1371/journal.pone.0082504

17. da Rocha, D. R.; de Souza, A. C. G.; Resende, J. A. L. C.; Santos, W. C.; dos Santos, E. A.; Pessoa, C.; de Moraes, M. O.; Costa-Lotufo, L. V.; Montenegro, R. C.; Ferreira, V. F. Org. Biomol. Chem. 2011, 9, 4315-4322. doi:10.1039/c1ob05209h

18. Ferreira, V. F.; Ferreira, S. B.; da Silva, F. d. C. Org. Biomol. Chem. 2010, 8, 4793-4802. doi:10.1039/c0ob00277a

19. Tseng, C.-M.; Wu, Y.-L.; Chuang, C.-P. Tetrahedron 2004, 60, 12249-12260. doi:10.1016/j.tet.2004.10.029

20. Shvartsberg, M. S.; Kolodina, E. A.; Lebedeva, N. I.; Fedenok, L. G. Tetrahedron Lett. 2009, 50, 6769-6771. doi:10.1016/j.tetlet.2009.09.110

21. Inman, M.; Moody, C. J. J. Org. Chem. 2010, 75, 6023-6026. doi:10.1021/jo101071c

22. Acosta, A.; de la Cruz, P.; De Miguel, P.; Diez-Barra, E.; de la Hoz, A.; Langa, F.; Loupy, A.; Majdoub, M.; Martin, N.; Sanchez, C.; Seoane, C. Tetrahedron Lett. 1995, 36, 2165-2168. doi:10.1016/0040-4039(95)00202-N

23. Oostveen, E. A.; Speckamp, W. N. Tetrahedron 1987, 43, 255-262. doi:10.1016/S0040-4020(01)89952-X

24. Comer, E.; Murphy, W. S. ARKIVOC 2003, 7, 286-296.

25. Bala, B. D.; Muthusaravanan, S.; Perumal, S. Tetrahedron Lett. 2013, 54, 3735-3739. doi:10.1016/j.tetlet.2013.04.125

26. Inoue, A.; Nomura, Y.; Kuroki, N.; Konishi, K. J. Synth. Org. Chem., Jpn. 1958, 16, 536-540. doi:10.5059/yukigoseikyokaishi.16.536

27. Kobayashi, K.; Yoneda, K.; Uchida, M.; Matsuoka, H.; Morikawa, O.; Konishi, H. Heterocycles 2001, 55, 2423-2430. doi:10.3987/COM-01-9358

28. Valderrama, J. A.; Astudillo, C.; Tapia, R. A.; Prina, E.; Estrabaud, E.; Mahieux, R.; Fournet, A. Chem. Pharm. Bull. 2002, 50, 1215-1218. doi:10.1248/cpb.50.1215

29. Tapia, R. A.; Alegria, L.; Pessoa, C. D.; Salas, C.; Cortés, M. J.; Valderrama, J. A.; Sarciron, M.-E.; Pautet, F.; Walchshofer, N.; Fillion, H. Bioorg. Med. Chem. 2003, 11, 2175-2182. doi:10.1016/S0968-0896(03)00122-6

30. Ryu, C.-K.; Choi, I. H.; Lee, J. Y.; Jung, S. H. Heterocycles 2005, 65, 1205-1214. doi:10.3987/COM-05-10341

31. Valderrama, J. A.; Espinoza, O.; Rodriguez, J.; Theoduloz, C. Lett. Org. Chem. 2009, 6, 278-281. doi:10.2174/157017809788490006 
32. Campiglia, P.; Aquino, C.; Bertamino, A.; De Simone, N.; Sala, M.; Castellano, S.; Santoriello, M.; Grieco, P.; Novellino, E.; Gomez-Monterrey, I. M. Org. Biomol. Chem. 2010, 8, 622-627. doi:10.1039/b918898c

33. Gomez-Monterrey, I.; Campiglia, P.; Aquino, C.; Bertamino, A.; Granata, I.; Carotenuto, A.; Brancaccio, D.; Stiuso, P.; Scognamiglio, I.; Rusciano, M. R.; Maione, A. S.; Illario, M.; Grieco, P.; Maresca, B.; Novellino, E. J. Med. Chem. 2011, 54, 4077-4091. doi:10.1021/jm200094h

34. Hamdan, A. J.; Al-Jaroudi, S. Arabian J. Sci. Eng., Sect. A 2003, 28 , 51.

35. Sartori, M. F. Chem. Rev. 1963, 63, 279-296. doi:10.1021/cr60223a005

36. Ueda, K.; Yamashita, M.; Sakaguchi, K.; Tokuda, H.; lida, A. Chem. Pharm. Bull. 2013, 61, 648-654. doi:10.1248/cpb.c13-00102

37. Möhrle, H.; Schulte Herbrüggen, G. Arch. Pharm. 1991, 324, 165-171. doi:10.1002/ardp.19913240307

38. Ohta, S.; Hinata, Y.; Yamashita, M.; Kawasaki, I.; Jinda, Y.; Horie, S. Chem. Pharm. Bull. 1994, 42, 1730-1735. doi:10.1248/cpb.42.1730

39. Ohta, S.; Hinata, Y.; Yamashita, M.; Kawasaki, I.; Shoji, T.; Yoshikawa, H.; Obana, Y. Chem. Pharm. Bull. 1994, 42, 1185-1190. doi:10.1248/cpb.42.1185

40. Reis, M. I. P.; Romeiro, G. A.; Damasceno, R.; da Silva, F. d. C.; Ferreira, V. F. Rev. Virtual Quim. 2013, 5, 283-299. doi:10.5935/1984-6835.20130027

41. Barluenga, M.; Bayón, A. M.; Campos, P.; Asensio, G.; Gonzalez-Nuñez, E.; Molina, Y. J. Chem. Soc., Perkin Trans. 1 1988, 1631-1636. doi:10.1039/P19880001631

42. Jordão, A. K.; Novais, J.; Leal, B.; Escobar, A. C.; dos Santos Júnior, H. M.; Castro, H. C.; Ferreira, V. F. Eur. J. Med. Chem. 2013, 63, 196-201. doi:10.1016/j.ejmech.2013.01.010

43. Guillemin, J. C.; Denis, J. M. J. Chem. Soc., Chem. Commun. 1985, 951-952. doi:10.1039/C39850000951

44. Smith, G. S.; Berlin, K. D.; Zisman, S. A.; Holt, E. M.; Green, V. A.; Van Der Helm, D. Phosphorus Sulfur Relat. Elem. 1988, 39, 91-111. doi:10.1080/03086648808072860

45. Cremer, D.; Pople, J. A. J. Am. Chem. Soc. 1975, 97, 1354-1358. doi:10.1021/ja00839a011

\section{License and Terms}

This is an Open Access article under the terms of the Creative Commons Attribution License (http://creativecommons.org/licenses/by/2.0), which permits unrestricted use, distribution, and reproduction in any medium, provided the original work is properly cited.

The license is subject to the Beilstein Journal of Organic Chemistry terms and conditions: (http://www.beilstein-journals.org/bjoc)

The definitive version of this article is the electronic one which can be found at: doi:10.3762/bjoc.11.137 